\section{Growth and physical quality of Paraserianthes falcataria (L) Nielsen seedling on ten types of transplanting media}

\author{
Slamet Santosa \\ Department of Biology, Faculty \\ of Mathematics and Natural Sciences, \\ Hasanuddin University, Indonesia
}

\section{Abstract \\ Growth and physical quality of} Paraserianthes falcataria (L) Nielsen seedling is determined by the quality and quantity of transplanting media. The aim of this research is to determine the best transplanting media for growing $P$. falcataria seedling. Research started with sowing $P$. falcataria seed in plastic container until the seedling grow. After 2 weeks of age, seedling was placed in ten types of transplanting media. Transplanting media consist of Sidoarjo's mud soil, rice husk, compost and cow manure. Each types of transplanting media were made from different concentration of mud, rice husk, compost and cow manure. Result showed that the highest growth of $P$. falcataria seedling was found in M4 with $31.0 \mathrm{~cm}$. However, this result was not significantly different with M1 which the high is $30 ., 6 \mathrm{~cm}$. Other $P$. falcataria seedlings showed varied growth with the value ranging from 27.6 to $29.9 \mathrm{~cm}$. M4 also showed highest stem diameter, root length and leaves number with value $0.50 \mathrm{~cm} ; 20.6 \mathrm{~cm} ; 50.1$ respectively. Root dry weight and stem+leaf dry weight were also highest on M4 with value $1.4 \mathrm{~g}$ and $4.9 \mathrm{~g}$. RRSL and Seed Quality Index were also highest on M4 with value 3.50 and 0.09 . It was concluded that M4 is the best transplanting media for $P$. falcataria seedling.

\section{Introduction}

Paraserianthes falcataria (L) Nielsen is the potential plant for industrial wood forest because it has high economical and ecological values. Wood from $P$. falcataria are mainly used for paper pulp industries. P. falcataria was also known for its ability to improve soil fertility, increase water management quality and create microclimate. ${ }^{1}$ Determination of seedling qualities were generally based on the assessment of three criteria: physical, physiological and genetics. ${ }^{2}$

Generally, seedling production of $P$. falcataria using transplating media consists of topsoil and organic compound. The use of top- soil as main mixture in transplanting media could rise negative impact to surrounding environment. If $50 \%$ topsoil were used as mixture in 1 billion transplanting media, it will be eroded approximately 5 million $\mathrm{m}^{3}$ of soil. ${ }^{3}$ Thus, the use of topsoil as material should be restricted and it is advisable to look for other alternative materials. There are some requirements that must be considered in making transplanting media. ${ }^{4}$ It should be porous for root aeration and drainage, has nutrient content, able to hold water, compact in texture and ability to support seedlings. ${ }^{5}$

An alternative material to substitute topsoil is mud soil from Sidoarjo. This material is abundant and is formed from oil drilling mudflow Lapindo Brantas Limited Company, Inc. Chemical analysis shows this mud soil consist of $62 \%$ clay and Cation Exchange Capacity (CEC) $42.48 \mathrm{me} / 100$ g. ${ }^{6}$ Clay component $>55 \%$ and it has potential ability to hold water in transplanting media. ${ }^{7}$ While CEC is important for soil fertility.

\section{Materials and Methods}

\section{Seedling of $P$. falcataria (L) Nielsen}

Research began with sowing $P$. falcataria seed in plastic container until the seedlings grow. Seedling was watered twice a day. After 2 weeks of ago, seedling was placed in 10 types of transplanting media consisting of: Sidoarjo's mud soil (S), Rice husk (R), Compost (C) and Cow Manure (M). Each type of transplanting media were made from different concentration of mud, rice husk, compost and cow manure. The ratio of mixture on each transplanting media were: M1 (20\% S: 40\% R: 20\% C: 20\% M); M2 (50\% S: 20\% R: $10 \%$ C: $20 \%$ M); M3 (50\% S: 20\% R: 20\% C: $10 \%$ M); M4 (50\% S: 40\% R: 10\% C); M5 (50\% S: 40\% R: 10\% M); M6 (80\% S: 10\% C: 10\% M); M7 (80\% S: 20\% R); M8 (80\% S: 20\% C); M9 (80\% S: $20 \% \mathrm{M})$ and M10 (100\% S). After 3 months, the growth and physical quality of $P$. falcataria was analyzed.

\section{Analysis of growth and transplanting media fertility}

Some growth parameters from $P$. falcataria seedlings that will be measured were the height of the plants $(\mathrm{cm})$, stem diameter $(\mathrm{cm})$, root length $(\mathrm{cm})$, leaves number, root dry weight (g), and stem+leaf dry weight (g). The dry weight obtained by drying samples on oven with temperature $105^{\circ} \mathrm{C}$. Chemical content in transplanting media: total N (\%), phosporus $\left(\mathrm{mgkg}^{-1}\right)$, potassium (me/100g) and physical properties: water holding capacity (\%) were analyzed. Chemical content analysis was conducted before transplanting media was used for growing $P$. falcataria seedling.
Correspondence: Slamet Santosa, Department of Biology, Faculty of Mathematics and Natural Sciences, Hasanuddin University, Tamalanrea Makassar, 90245, South Sulawesi, Indonesia. Tel.: +62 85242113320 .

E-mail: slamet_santosa@science.unhas.ac.id

Key words: Growth; physical quality; transplanting media.

Acknowledgements: the authors wish to thank Prof. Dr. Ir. Zaenal Kusuma, Dr. Budi Prasetya and Dr. Bagyo Yanuwiardi of Brawijaya University for insightful and provocative discussions. His encouragement was instrumental in the completion of this work.

Contributions: the contributed equally.

Conflict of interest: the author declares no potential conflict of interest.

Received for publication: 19 November 2015.

Revision received: 22 December 2015.

Accepted for publication: 23 December 2015.

This work is licensed under a Creative Commons Attribution-NonCommercial 4.0 International License (CC BY-NC 4.0).

\section{(C) Copyright Sl. Santosa , 2016}

Licensee PAGEPress srl, Italy

International Journal of Plant Biology 2016; 7:6317 doi:10.4081/pb.2016.6317

\section{Assessment of the physical quality}

There are two parameters to assess physical quality of $P$. falcataria seedling: i) the Ratio of Root dry weight with Stem+Leaf dry weight (RRSL), and ii) Seed Quality Indexs (SQI). The formula used to analyzed are as follows: ${ }^{8}$

$$
\begin{aligned}
& R R S L=\frac{R d w(g)}{S l d w(g)} \\
& S Q I=\frac{R d w+S l d w}{R R S L+\frac{H}{D}}
\end{aligned}
$$

where: RRSL, ratio of root dry weight with stem+leaf dry weight; SQI, Seed Quality Index; Rdw, root dry weight (g); Sldw, Stem+leaf dry weight $(\mathrm{g}) ; \mathrm{H}$, height plant $(\mathrm{cm}) ; \mathrm{D}$, stem diameter $(\mathrm{cm})$.

\section{Data analysis}

The data were analyzed using $\mathrm{F}$ test with confidence interval 95\%. Furthermore, if the treatment significantly affected the measurement of parameters, the analysis would be continued with Duncan's test. The analysis of the feasibility of seedling ready for planting were 
compared with the National Standard of Indonesia (SNI), which determined the average of high plant (seedling) values $\geq 30.0 \mathrm{~cm}$ and stem diameter $\geq 0.50 \mathrm{~cm}^{9}$

\section{Results and Discussion}

\section{Growth and transplanting media fertility}

The highest growth of $P$. falcataria seedling was found in M4. However, the growth was not significantly different with the high growth of M1 growth. Growths of other transplanting media (M2, M3, M5, M6, M7, M8, M9 and M10) were varied, ranging from 27.6 to $29.9 \mathrm{~cm}$ (Table 1). These results were not different with some results from other researchers. ${ }^{1}$ Seedling on transplanting media with topsoil and compost resulted in high growth $32.3 \mathrm{~cm} .{ }^{10}$ While transplanting media with manure supplement was only resulted $27.4 \mathrm{~cm}^{11}$ Transplanting media with manure and compost showed various high growths ranging from 14.52 to $30.04 \mathrm{~cm} .{ }^{9}$ According to SNI, the high growth of $P$. falcataria seedling $\geq 30.0 \mathrm{~cm}$ was eligible to be planted in the field.

The highest root growth of $P$. falcataria seedling was also found in M4 with length 20.6 $\mathrm{cm}$. However, this length was not significantly different with root growth of M2. The use of $40 \%$ rice husk as mixture in M4 transplanting media provided large space for root of seedling to grow. ${ }^{6}$ Rice husk also increased the porocity of media, not easy to decompose and produced less solid media. ${ }^{12}$ The plants grew better when having adequate growing space. Growing space affected root development. Limited growing space will disturb root growth.

Roots are important parts of plant, which affect growth and development. Roots are used by the plant to absorb nutrients and water for the growth of leaves and stems. Better root growth in M4 transplanting media influenced the number of leaves and stem diameter of $P$. falcataria seedling. Leaves are primary location for photosynthesis. ${ }^{13}$ The number of leaves is a major determinant for growth rate. More leaves number will increase high growth. ${ }^{14}$ Meanwhile, stem diameter is influenced by photosynthetic rate, which depend on leaf growth. ${ }^{8}$ Lower photosynthetic rate will inhibit stem diameter growth. ${ }^{15}$ On the other hand, growth of plant is the final manifestation of photo synthetic processes.

The growth of $P$. falcataria seedling varies in 10 types of transplanting media. This happens because each transplanting media has different quality and quantity. ${ }^{16}$ Good quality media contains nutrient elements $\mathrm{N}, \mathrm{P}, \mathrm{K}$ and water. Meanwhile media has optimum quantity if they provide growing space for root to grow. From chemical content analysis, result showed that nutrient element varied among transplanting media. Total $\mathrm{N}$ ranged from 0.12 to

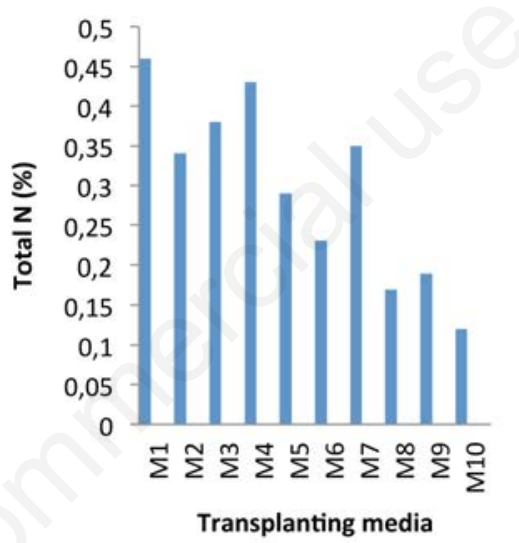

Figure 1. Contents of total N and P Bray on ten types of transplanting media.

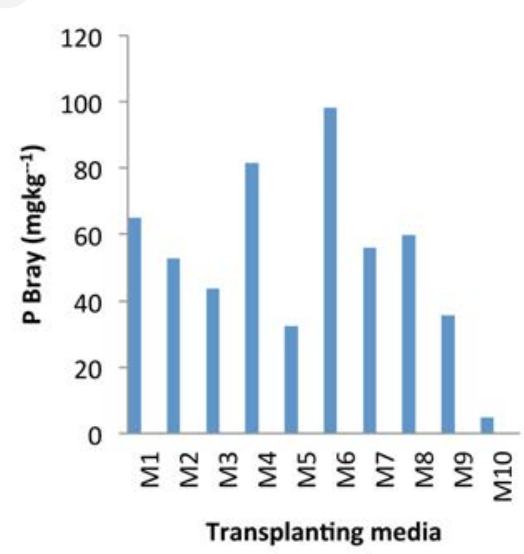

$0.46 \%$, P Bray availability ranges from 4.8 to $98.12 \mathrm{mgkg}^{-1}$ and $\mathrm{K}$ availability ranged from 0,09 to $2,54 \mathrm{me} / 100 \mathrm{~g}$. Analysis of water holding capacity ranged from $55.0-68$. 57\% (Figures 1 and 2). ${ }^{17}$ Total $\mathrm{N}$ ranged from 0.21 to $0.50 \%$ which is categorized as middle fertility. P Bray availability value was $>35.0 \mathrm{mgkg}^{-1}$ and $\mathrm{K}$ available value $1.0 \mathrm{me} / 100 \mathrm{~g}$. Both values were categorized as very high fertility.

Based on these criteria, the transplanting media (M1, M2, M3, M4, M5, M6 and M7) have total $\mathrm{N}$ ranged from 0.23 to $0.46 \%$, and categorized as middle class fertility. While transplanting media (M1, M2, M3, M4, M6, M7, M8 and M9) have P Bray ranged from 35.72 to 98.12 $\mathrm{mgkg}^{-1}$ and $\mathrm{K}$ availability ranged from 1.02 to $2.54 \mathrm{me} / 100 \mathrm{~g}$. Both ranged of value categorized as high-class fertility. Only M10 categorized as infertile because it has total N $0.12 \%$, P Bray availability $4.8 \mathrm{mgkg}^{-1}$ and $\mathrm{K}$ availability 0.09 me/100 g. M10 consist of $100 \%$ mud soil without rice husks, compost and cow manure. ${ }^{6}$ This sample made from Sidoarjo's mud soil from

Table 1. Duncan's test of growth and physical quality of $P$. falcataria $(\mathrm{L})$ Nielsen seedling.

\begin{tabular}{|c|c|c|c|c|c|c|c|c|}
\hline $\begin{array}{l}\text { Code of } \\
\text { transplanting } \\
\text { media }\end{array}$ & $\begin{array}{c}\text { Height plants, } \\
\text { cm }\end{array}$ & $\begin{array}{l}\text { Stem diameter, } \\
\text { cm }\end{array}$ & $\begin{array}{l}\text { Length root, } \\
\text { cm }\end{array}$ & $\begin{array}{l}\text { Leaves } \\
\text { number }\end{array}$ & $\begin{array}{l}\text { Root dry } \\
\text { weight, g }\end{array}$ & $\begin{array}{l}\text { Stem + leaf } \\
\text { dry weight, g }\end{array}$ & RRSL & SQI \\
\hline M1 & 30.6 & $0.50^{c}$ & $19.8^{b c}$ & $48.2^{\mathrm{b}}$ & $1.3^{\mathrm{c}}$ & $4.7^{\mathrm{cd}}$ & $3.62^{\mathrm{a}}$ & $0.09^{\mathrm{a}}$ \\
\hline M2 & $28.9^{a b}$ & $0.48^{b}$ & $20.4^{c}$ & $50.0^{\mathrm{bc}}$ & $1.3^{\mathrm{c}}$ & $4.7^{\mathrm{cd}}$ & $3.62^{\mathrm{a}}$ & $0.09^{a}$ \\
\hline M3. & $29.9^{b}$ & $0.50^{c}$ & $19.6^{\mathrm{bc}}$ & $49.2^{\mathrm{b}}$ & $1.3^{c}$ & $4.8^{\mathrm{d}} \mathrm{e}$ & $3.69^{\mathrm{a}}$ & $0.09^{a}$ \\
\hline M4 & $31.0^{c}$ & $0.50^{\mathrm{c}}$ & $20.6^{\mathrm{c}}$ & $50.1^{\mathrm{c}}$ & $1.4^{\mathrm{cd}}$ & $4.9 \mathrm{e}$ & $3.50^{\mathrm{a}}$ & $0.09^{\mathrm{a}}$ \\
\hline M5 & $28.3^{\mathrm{a}}$ & $0.48^{b}$ & $19.8^{b c}$ & $48.0^{\mathrm{b}}$ & $1.3^{c}$ & $4.3^{\mathrm{bc}}$ & $3.31^{\mathrm{a}}$ & $0.09^{\mathrm{a}}$ \\
\hline M6 & $28.1^{\mathrm{a}}$ & $0.41^{\mathrm{a}}$ & $10.0^{\mathrm{a}}$ & $44.4^{\mathrm{ab}}$ & $0.4^{\mathrm{a}}$ & $4.0^{\mathrm{ab}}$ & $10.00^{b}$ & $0.06^{\mathrm{b}}$ \\
\hline M7 & $28.4^{\mathrm{a}}$ & $0.48^{b}$ & $19.0^{\mathrm{a}}$ & $48.4^{b}$ & $1.1^{b}$ & $4.4^{\mathrm{bcd}}$ & $4.00^{\mathrm{a}}$ & $0.09^{\mathrm{a}}$ \\
\hline M8 & $28.3^{\mathrm{a}}$ & $0.42^{\mathrm{a}}$ & $9.0^{\mathrm{a}}$ & $44.4^{\mathrm{ab}}$ & $0.4^{\mathrm{a}}$ & $4.0^{\mathrm{ab}}$ & $10.00^{b}$ & $0.06^{b}$ \\
\hline M9 & $27.6^{\mathrm{a}}$ & $0.42^{\mathrm{a}}$ & $8.4^{\mathrm{a}}$ & $42.0^{\mathrm{ab}}$ & $0.4^{\mathrm{a}}$ & $4.0^{\mathrm{ab}}$ & $10.00^{b}$ & $0.06^{\mathrm{b}}$ \\
\hline M10 & $27.8^{\mathrm{a}}$ & $0.41^{\mathrm{a}}$ & $8.0^{\mathrm{a}}$ & $33.2^{\mathrm{a}}$ & $0.4^{\mathrm{a}}$ & $3.8^{\mathrm{a}}$ & $9.50^{\mathrm{b}}$ & $0.06^{b}$ \\
\hline
\end{tabular}

$\mathrm{a}, \mathrm{b}, \mathrm{c}, \mathrm{dV}$ Values in columns followed by the same letter are not significantly different level of 95\%CI. RSSL, ratio of root dry weight with stem+leaf dry weight; SQI, Seed Quality Index. 
mud out of the depths over of $100 \mathrm{~m},{ }^{18}$ where organic material was limited.

The ten types of transplanting media had a water holding capacity by varying amounts (Figure 2). Results of this analysis showed the water holding capacity of all transplanting media to provide water $50 \%$ to support the growth of $P$. falcataria seedling. ${ }^{19}$ The water holding capacity $>50 \%$ could keep moisture in order to avoid the risk of drought media. ${ }^{20}$ The water in the plant served as the main compound forming protoplasm, solvent and means of transport of mineral nutrients from the soil to plants and raw materials photosynthesis. ${ }^{21}$ Plant growth depended on the amount of water available in the soil. Growth would be limited by the very low water content and the very high one. However, plants had many ways to set themselves towards the conditions of limited water available. Water holding capacity was influenced by the existing pores. The quality and quantity of transplanting media were influenced materials. ${ }^{7}$ The clay component was over of $55 \%$, very potential to hold water in transplanting media. ${ }^{22}$ Rice husks had a role in the improvement of soil physical properties, include: i) improving soil structure or soil loosening, and ii) add water absorption. ${ }^{23}$ The addition of compost or cow manure at doses of 40 tonha $^{-1}$ is able to increase the total $\mathrm{N}$ from 0.092 to $0.134 \%$.

\section{Physical quality}

Physical quality of seeds is an expression or a picture of a seed which is expected to have high vitality and adaptable after planting. Quality of seeds can be judged from physical parameters such as the ratio of RRSL and seed quality index. ${ }^{16}$ The ten types of transplanting media produced different of physical quality performances (Figure 3). The result of RRSL calculation showed that the transplanting media (M1, M2, M3, M4, M5 and M7) have a values ranged from 3.31 to 4.00 . The RRSL on
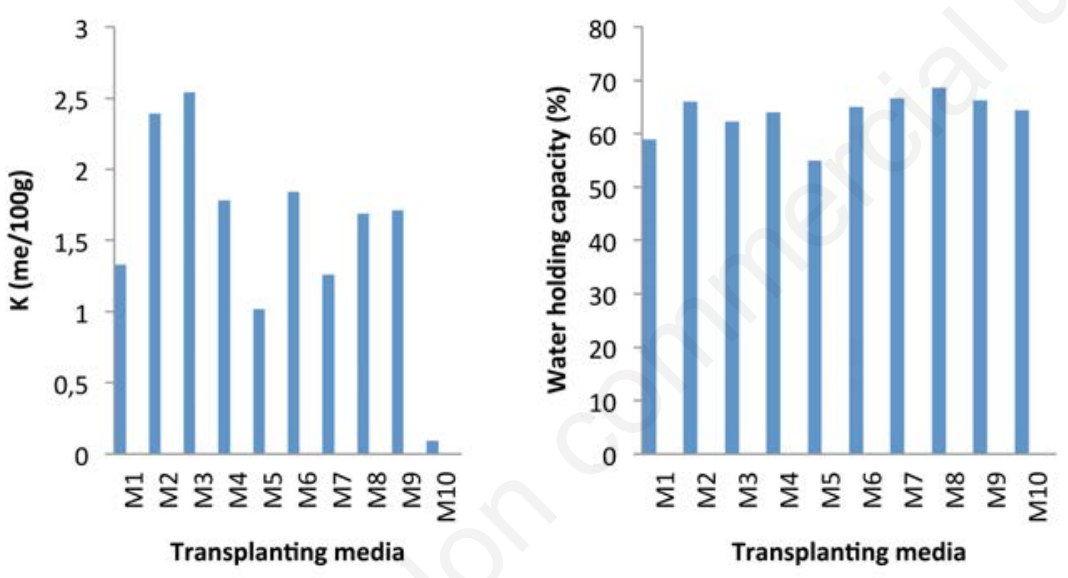

Figure 2. Contents of $\mathrm{K}$ and water holding capacity on ten types of transplanting media.

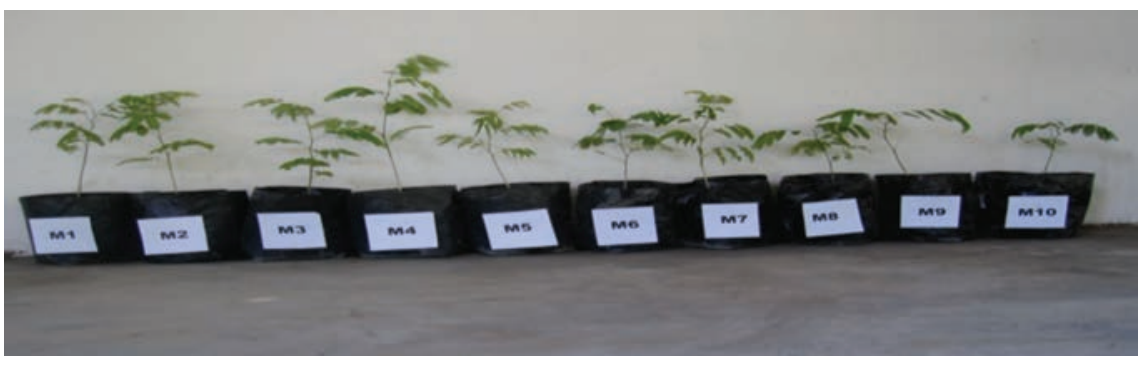

Figure 3. Physical quality performances of $P$. falcataria $(\mathrm{L})$ Nielsen seedling on ten types of transplanting media.

transplanting media (M6, M8, M9 and M10) have a values ranged from 9.50 to $10.00 .^{24}$ The RRSL is an important factor in plant growth which illustrates the comparison between the ability of water and mineral absorption by the process of transpiration and photosynthesis of the plant area. ${ }^{25}$ The RRSL is identified with the state of the canopy and seedling, where the canopy growth influenced environmental conditions and activities of root growth. While the shoot meristem is affected by the media and the results of photosynthesis. ${ }^{26}$ The RRSL values ranged from 2 to 5 when planted in the field will be easier to live. ${ }^{27}$ The value of the RRSL can be used as the basis of quality seeds. The RRSL lower value indicates seedlings have the power of life and higher adaptability.

The result of SQI calculation showed that the transplanting media (M1, M2, M3, M4, M5 and M7) have an equal value of 0.09 ; while the SQI on transplanting media (M6, M8, M9 and M10) have an equal value of $0.06 .^{24}$ The SQI represents the value of quality seeds that can describe the ability of a particular seed may or may not adapt to the new environment. The SQI higher value indicates that the seedlings have the higher quality and when planted in the field will decrease the death rate. ${ }^{27}$ The SQI values $\geq 0.09$, adaptable and high vitality after planting. ${ }^{28}$ The SQI shows the existence of a balance translocation of photosynthetic plant organs into a canopy (stems and leaves) as well as to the roots. There is a balance translocation of photosynthetic organs of plants to cause the seed to have a balance of growth between the canopy and the roots.

\section{Conclusions}

It was concluded that M4 with mixture consisting of 50\% Sidoarjo mud soil, $40 \%$ Rice husk and 10\% Compost is the best transplanting media for $P$. falcataria seedling.

\section{References}

1. Suhartati. Application of inoculum EM4 and its effect on growth of Paraserianthes falcataria L.) seedling. J Forest Nat Conserv Res 2008;5:55-65.

2. Pramono, Suhaendi H. Benefits of certification source seed. Research and development center for forest and nature conservation. Bogor 2006:49-61.

3. ITT0. Status of tropical forest management 2005. Special edition of the tropical forest. Yokohama, Japan. 2006. pp 1-2.

4. Hartmann HT, Kester DE, Davies FT, Geneve RL. Plant propagation principles and practices. Prentice Hall, Upper Saddle 
River, New Jersey, USA: 2002. pp 115-6.

5. Abdulrahman YA, Kako BC. Effect of growing media on growth and flowering of different cultivars hyacinths (Hya cinthus orientalis L.). J Agric Sci Technol 2012;8:1100-8.

6. Santosa S, Kusuma Z, Prasetya B, Yunuwiadi B. The effect of sidoarjo's mud soil with organic materials toward the growth of Samanea saman Merr. Acad Res Int J 2014;5:61-2.

7. Syukur A. Influence of organic matter to the soil properties and growth of Caisim sp. J Soil Environ Sci 2005;5:30-8.

8. Daniel TW, Helms JA, dan Baker FS. Principles of Silviculture. Gadjah Mada University Press. Yogyakarta 1992. pp 103-4.

9. Darori. Technical guidelines for assessment of quality seeds plant forest. Directorate general of land rehabilitation and social forestry, Department of Forestry; Jakarta: 2007. pp 45-7.

10. Hani A, Mile MY. Testing enrichment techniques in organic matter and its effect on growth of P. falcataria seedling. Partner Plant Forest 2006;1:5-8.

11. Muswita, Pinta M, Lia H. Effect of organic fertilizer on the growth of Paraserianthes falca taria L. Biol J 2008;1:15-8.

12. Hidayat Y. Root growth response of Para serianthes falcataria against density and water content on yellow red podzolic soil. Bogor Agricultural University. Bogor 2000;1:25-40.

13. Marjenah. Effects of different shades against the growth and morphological response on two types of timber tree seedling. J Forest Rimba Kali mantan 2001;6:2.

14. Simorangkir BDAS. The Analysis of Riap Dryobalanopslanceolata Burck on different line in collection forest. East Borneo: University of Mulawarman 2004:5-6.

15. Khan NA, Syeed S, Masood A, et al. Application of salicylic acid increases contents of nutrients and antioxidative metabolism in mungbean and alleviates adverse effects of salinity stress. Int $\mathrm{J}$ Plant Biol 2010;1:1-8.

16. Junaedi A. Growth and physical quality of Jabon (Anthocephalus cadamba Mig) on polybag and politub. Plant Forest Res J 2009;7:15-21.

17. Rosmarkam A, Yuwono NW. Soil fertility studies. Cani sius Press. Yogyakarta 2002:103-4.

18. Prasetyo BH. Differences in soil properties of various materials Vertisol parent. Indones J Agric Sci 2007;9:20-31.

19. Syamsuwida D, Yuniarti N, Daughter KP. Effect of fertilizer used, seedling media and Rhizobium inoculation on growth of Kihiang (Albizia procera) and Johar (Cassia siamea) seedling. Bull Seed Technol 2001;8:133-46.

20. Taiz L, Zeiger E. Plant Physiology. Third Edition. Sinauer Asso ciates, Inc., Publishers. Sunderland, Massachusetts: 2002. pp 667-8.

21. Soil fertility. Directorate general of higher education, Department of Education and Culture; Jakarta: 1991. pp 90-2.
22. Atmojo SW. Application of organic matter and soil fertility against the management efforts. Inauguration of Faculty of Agriculture, University of Surakarta; Surakarta: 2003. pp 5-22.

23. Syukur A, Indah NM. Influence of organic fertilizer kinds toward the growth and yield of Zingiber officinale Rosc. in Inceptisol, Karanganyar. J Soil Environ Sci 2006;6:124-31.

24. Napitupulu DR. Influence of sawdust and rice straw compos ting with Trichoderma viridae as media toward the growth of Paraserianhes falcataria L (Nielsen) seedling. Faculty of forestry, Bogor agricultural university. Bogor 2002;1:20-9.

25. Hatmani SS. Effect of media composition and dosage of N, P, K fertilizer on growth of Paraserianthes falcataria L Nielsen seedling. Bogor Agricultural University. Bogor 1995;1:20-6.

26. Mindawati N, Yusnita S. The influence of media toward the growth of Acacia mangium Wild seedling. J Forest Nat Cons Res 2005;2:53-9.

27. dan Hendromono D. Possible use of organic waste from fiber palm oil with mixed rice husk and top soil as media toward the growth of Mahogany (Swietenia macrophylla King). Forest Res Bull 2001;628:1326.

28. Indriyanto. Effects of transplanting period and media on seedling growth quality of Mahogany (Swietenia macrophylla King). J Tropic Forest Manage 1998;4:23-8. 